\title{
INTRODUCTION : THE EU-NETWORK CRAYNET- IMPACTS ON FUNDAMENTAL QUESTIONS
}

\author{
C. SOUTY-GROSSET
}

\begin{abstract}
UMR 6556, Génétique et Biologie des Populations de Crustacés, Université de Poitiers, 40, avenue du Recteur Pineau, F-86022 Poitiers Cedex, France.

E-MAIL: catherine.souty@univ-poitiers.fr; Craynet@univ-poitiers.fr; http://labo.univ-poitiers.fr/craynet
\end{abstract}

Reçu le 5 avril 2005

Received April 5, 2005

\begin{abstract}
The European network CRAYNET "European crayfish as keystone species-linking science, management and economics with sustainable environmental quality" emphasises knowledge-based management strategies. The CRAYNET meetings concentrate on certain topics: monitoring in conservation and management of natives; interaction between natives and aliens; control of aliens; habitat restoration; reintroduction and restocking; legislation; education. The Irish meeting (Kilkenny, 2003) "The endangered native crayfish Austropotamobius pallipes: bioindicator and heritage species" initiated debates about (1) what is a bioindicator, a flagship species or a heritage species?; (2) the problem of species complexes and the need to clarify and resolve taxonomy before management; and (3) what is meant by biodiversity in the context of European crayfish? The Norwegian meeting (Halden, 2003) "European native, crayfish with a special focus on Astacus astacus: linking socioeconomics and conservation " involved roundtables about (1) threats to indigenous population of crayfish at a landscape level; (2) exploitation, conservation, legislation; (3) reintroduction of indigenous crayfish, habitat restoration and monitoring; and (4) the urgent need for joint research about pathology. The present meeting (Innsbruck, 2004) "European native crayfish in relation to land-use and habitat deterioration with a special focus on Austropotamobius torrentim" aims to identify the species protection programs, to examine if legislation is working well in protecting vulnerable species, the state of advances about conservation genetics and how to make progress in education of the public. A permanent connection between the 12 core members provides opportunities to check the needed lines of research, to prepare recommendations, and to gather information for an atlas on the distribution of crayfish species in Europe as well as to prepare leaflets for the public.
\end{abstract}

Key-words: Europe, management, indigenous species, aliens, heritage species, socioeconomics, database atlas.

\section{INTRODUCTION : LE RÉSEAU THÉMATIQUE EUROPÉEN CRAYNET - IMPACTS SUR DES QUESTIONS FONDAMENTALES}

\section{RÉSUMÉ}

Le réseau thématique européen CRAYNET intitulé "European crayfish as keystone species-linking science, management and economics with sustainable environmental 
quality" met l'accent sur les stratégies de gestion basées sur la connaissance. Les réunions CRAYNET ont pour but de discuter régulièrement des thèmes tels que conservation et gestion des populations natives, interaction entre écrevisses natives et écrevisses exotiques, contrôle des espèces exotiques, restauration de l'habitat, réintroduction et repeuplement, législation, éducation. La réunion irlandaise (Kilkenny, 2003) intitulée "The endangered native crayfish Austropotamobius pallipes: bioindicator and heritage species" a fédéré des débats portant sur (1) Que représente une espèce bioindicatrice, une espèce phare ou une espèce patrimoniale ? (2) le problème des espèces complexes et les clarifications taxonomiques à résoudre avant toute conduite de gestion (3) comment appréhende-t-on la biodiversité concernant les populations d'écrevisses natives d'Europe ? La réunion norvégienne (Halden, 2003) intitulée "European native, crayfish with a special focus on Astacus astacus: linking socioeconomics and conservation" a initié des tables rondes sur (1) menaces pour les populations patrimoniales à l'échelle du paysage; (2) exploitation, conservation, législation; (3) réintroduction des espèces patrimoniales, restauration de l'habitat et contrôle; (4) le besoin urgent d'avancer les recherches en pathologie. La réunion faisant l'objet de ce volume (Innsbruck, 2004) et intitulée "European native crayfish in relation to land-use and habitat deterioration with a special focus on Austropotamobius torrentium" a pour but d'identifier les programmes pour la protection des espèces, d'examiner si la législation est bien appliquée pour les espèces vulnérables, de voir l'état d'avancement des recherches en génétique de la conservation et comment progresser sur le problème de l'éducation du public. Une connexion permanente entre les 12 pays membres donne l'opportunité d'identifier les lignes de recherché futures, de préparer des recommandations et de rassembler des données pour éditer un atlas de distribution des écrevisses natives d'Europe ainsi que de préparer des brochures de vulgarisation pour le public.

Mots-clés: Europe, gestion, espèces natives, espèces exotiques, espèces patrimoniales, socioéconomie, atlas de distribution.

\section{INTRODUCTION}

Crayfish are among the largest and longest-lived of freshwater invertebrates, and their wide-ranging activity means that they are not only appreciated as heritage species whose loss would diminish freshwater biodiversity (SOUTY-GROSSET, GRANDJEAN and GOUIN, 2003), but they also act as keystone species, regulating biodiversity in streams and lakes.

The CRAYNET project subtitled "European crayfish as keystone species- linking science, management and economics with sustainable environmental quality" involves eleven countries (France, Ireland, Italy, Germany, Sweden, Austria, Norway, United Kingdom, Poland, Finland and Spain). It was set up as a network of European researchers and managers to develop knowledge-based management strategies and a common approach to management. The aim is to highlight and stimulate research activities into the three threatened crayfish species native to the European Community, and to disseminate findings on these heritage species to the wider public.

Consequently the Network is organised around three strands corresponding to the three indigenous crayfish present in Europe, their distribution being as described by HOLDICH (2002, 2003): Austropotamobius pallipes (western and southern Europe), considered as a threatened water quality bioindicator; Astacus astacus (northern Europe), which has a strong traditional and current fisheries value; and Austropotamobius torrentium (Circum-alpine countries) a species from the circum alpine region and whose status needs to be clarified. 
The CRAYNET meetings bring together crayfish researchers and managers to work towards a common approach to management techniques, and to develop recommendations for optimal management strategies at a European scale. Moreover, ongoing CRAYNET activities will provide tangible results such as the inventory of research and management programmes on European crayfish and the preparation of an atlas on the distribution of crayfish species in Europe (website:).

\section{"THE ENDANGERED NATIVE CRAYFISH AUSTROPOTAMOBIUS PALLIPES. BIOINDICATOR AND HERITAGE SPECIES" (Irish meeting, Kilkenny, 2003: BFPP vol. 370-371)}

Ireland was selected because this country has the largest population of whiteclawed crayfish in Europe, and because it is the unique European territory without alien crayfish species (REYNOLDS, DEMERS and MARNELL, 2002).

The meeting took place in the Nore river valley and the historic city of Kilkenny as a base. White-clawed crayfish are now thought to have been introduced from western France to this area of southeastern Ireland (GOUIN et al., 2003), perhaps by monastic orders in mediaeval times. The conference allowed broad scope for discussion and discovery around several themes:

Is $A$. pallipes native? We now have evidence of introductions and translocations across its range within historical times, casting doubt on its truly indigenous status in some countries.

Is $A$. pallipes one or several species? The genetic evidence is that "A. pallipes" is not homogeneous across its range. In the north the species is clear (GRANDJEAN and SOUTY-GROSSET, 2000, GOUIN, 2001) but further south, there are sub-species and perhaps sibling species to consider (GRANDJEAN et al, 2000, GRANDJEAN, FRELONRAIMOND et SOUTY6GROSSET, 2000, SOUTY-GROSSET, GRANDJEAN and GOUIN, 2003, FRATINI et al, 2005).

This then raises a further series of questions:

- Do the different forms have diverse ecological tolerances or requirements?

- What is the status of $A$. pallipes as a bioindicator, and how valid is this across its geographical and genetic range?

- Finally, how can such a complex taxon be protected, as an acknowledged heritage species, through appropriate management and legislations?

The statutory problem of recognising a new taxon formerly included in A. pallipes under European legislation must be resolved: the group proposed the inclusion of A. italicus in the invertebrate Red Book data.

Finally the group proposed $A$. pallipes as a new supra-species. It is thus urgent to revise the international and national legislation and ensure that the concerned countries transfer this information to the relevant authorities. This is one of the goals of the European network CRAYNET and more advances were made during the second meeting in Norway.

Is austropotamobius pallipes a good bioindicator? What is a bioindicator, and how well do crayfish match this concept? The question was debated because there is generally a great need for methods to assess human impacts on aquatic ecosystems and evaluate restoration and management measures. More knowledge is needed of the tolerance limits of $A$. pallipes sub-species in regard to eutrophication, organic enrichment, water chemistry and chemical pollutants, and habitat characteristics. Some initial contributions have recently been published (DEMERS, REYNOLDS and CIONI, 2003; FÜREDER et al., 2003; TROUILHÉ et al., 2003), but the value of $A$. pallipes as a bioindicator is still debated. 
The group recognized a lack of knowledge of the effect of environmental factors or the combined effect of two (or more) factors. Such studies are now in progress (TROUILHÉ et al., 2003). Considering the result of this discussion, and also because of their cultural heritage values, a much better keyword instead of "bioindicator" would be "flagship species". But also because of their cultural heritage, crayfish may act as a "surrogate species" to be used in biological conservation (FÜREDER and REYNOLDS, 2003).

\section{"EUROPEAN NATIVE CRAYFISH WITH A SPECIAL FOCUS ON ASTACUS ASTACUS: LINKING SOCIOECONOMICS AND CONSERVATION" (Norwegian meeting, Halden, 2003: BFPP vol. 372-373)}

The meeting programme addressed socio-cultural and socioeconomic aspects, conservation and restocking, trade regulations, genetic variation, survey methods, and perspectives on the past, present and future of crayfish pathology in Europe.

Crayfish had an important role in the eating habits across Europe, habits that in many countries have become extinct (SWAHN, 2004), except in Scandinavia. This cultural importance has led to strong controls on fishing, which safeguards conservation of crayfish populations (EDSMAN, 2000).

Threats to indigenous crayfish populations - crayfish on a landscape level. A comparison of threats to European indigenous crayfish indicated that land-use is considered as the second most important impact on crayfish after that of non-indigenous species. It also became evident that data on crayfish distribution and land-use are both readily available in many European countries. They often exist as geo-referenced data in formats usable with Geographical Information Systems (GIS). In spite of this, it is rather surprising that there is only one case available that attempted to link land-use data with crayfish presence at a landscape level. SCHULZ and SCHULZ (2004) proved that GIS is a suitable tool for the assessment of land-use effects and overall human impact on crayfish distribution at a landscape level.

Reintroduction of indigenous crayfish, habitat restoration and monitoring. The aim was to discuss reintroduction of indigenous crayfish and habitat restoration, so as to provide practical recommendations of value to environmental authorities, decision makers and local managers (HOLDICH and ROGERS, 2000; HOLDICH, REYNOLDS and EDSMAN, 2002; PEAY, 2000; TAUGBØL and PEAY, 2004). A (re)introduction may be appropriate:

a) to reintroduce a population recently lost,

b) to extend the distribution of an indigenous crayfish species into its historic range,

c) to create new or isolated populations to conserve genetic diversity or the species genetic distinctiveness and possible spread of diseases must be considered.

In general, major constraints in a restocking project are money and availability of stocking material. General recommendations are to use adults and young/juveniles as available, to stock as many crayfish as can be afforded and several times (see REYNOLDS, DEMERS and MARNELL, 2000) and, if short of stock, to boost through hatchery rearing.

A key factor in the protection of indigenous crayfish populations is the knowledge and attitude of local people. Objectives and actions should be agreed with local stakeholders to improve chances of success.

There need be no contradiction between exploitation and conservation provided that a balance between utilisation and overexploitation can be found. In some European countries there are strong traditions connected to crayfish fisheries. Exploitation, in the form of a controlled fishery, may be an essential tool in conservation by increasing the general awareness and by involving more people in the task of protecting the species. 
Local guidelines for sustainable exploitation should be produced. Other ways of utilising indigenous crayfish, e.g. farming indigenous crayfish for restocking purposes, are possible.

Crayfish diseases. Discussions opened with an overview of existing epizootics in crayfish (EDGERTON and JUSSILA, 2004). In the last 70 years, much of the research conducted in crayfish pathology has concentrated on fungi, especially improving diagnostic techniques for Aphanomyces astaci. On the other hand, viruses have proved to be the most important pathogens in the growing global crustacean aquaculture and fishery industries. Rickettsia-like organisms (RLO) are also important. Critically, the full range of diagnostic techniques are rarely utilised in studies of crayfish pathology in Europe. Such limitations in crayfish pathology have major repercussions in management of freshwater crayfish. We need a trans-European Community research and education programmes to address this serious issue, another goal of the CRAYNET network.

Exploitation, legislation and conservation. Legislation dealing with crayfish varies a lot between different European countries and even within countries, due to differences in history, culture, economy and political systems. Since the analysis of legislation in Poitiers (VIGNEUX et al., 2002), the only change has been the recently imposed live crayfish import ban in Sweden. A more uniform legislation is needed. One of the working groups in Poitiers (2001) recommended that the noble crayfish and the stone crayfish should be integrated into Annex II in the EU Habitat Directive. Participants from Sweden, Norway and the Baltic countries thought that this might have an adverse effect in countries where the use of noble crayfish is a prerequisite for the conservation of the species. However, it is possible for a species to be in both Annexes II and V and at the same time utilised for fisheries, as is the case of the Atlantic salmon. The group therefore agreed to renovate the recommendation to include also $A$. astacus and $A$. torrentium in Annexes II and V of the Directive (EDSMAN and SMIETANA, 2004). (This last species is now included in Annex II).

The EU Water Framework Directive has recently been adopted. The Directive aims at having good quality surface water across whole catchment areas regardless of national borders. Good status also includes the preservation of biological diversity, of which indigenous crayfish are certainly one part. This will lead to increased monitoring efforts, these being advantageous to the indigenous crayfish. In order to conserve native crayfish one must know what species, either indigenous or alien, are present and where they occur. One of the tasks of the CRAYNET network is to produce an atlas of the European crayfish distribution.

Importantly, legislation to control the spread of alien crayfish is urgently needed (SIBLEY, 2003).

It was agreed that the key to solving the problem of accidental introductions was knowledge and information as well interest among stakeholders and the general public.

Educational material aimed at schools, museums, stakeholders and managers should be produced. As PUKY et al., 2002, (2002) indicated, the younger generation is probably the best target for information about indigenous crayfish. Children are curious and receptive and can in turn educate their parents. Other target groups for educational material are the people directly involved with crayfish and their organisations, not only fishermen but also landowners, anglers, fish shops, customs personnel and those utilising rivers and lakes for recreation.

Atlas on distribution of european crayfish. CRAYNET has initiated a debate on the compilation of data on indigenous and non-indigenous crayfish (ICS and NICS) in Europe, under the initiative of David HOLDICH and Pierre NOËL. 
HOLDICH (2002) provides an up-to-date overview of the distribution of ICS and NICS in Europe, but this is based only on an extensive literature search. Government agencies, researchers, consultants should all be involved to obtain the most comprehensive picture of crayfish distribution. The atlas, synthesizing all data up to 2004, will provide precise and up to date information on the distribution of all the species of crayfish living in Europe (indigenous or introduced). It will be a vital tool to determine what countries or regions must be involved in the management of these species. Areas at risk for crayfish plague will also be mapped. Each species and its habitats will be described and past and present distribution will be commented on. This atlas will be useful both to scientists and to regional or national environmental administrations or conservation organisations to implement action plans. Cross-border actions should lead to eventual harmonisation of legislation.

\section{CONCLUSIONS}

Finally, CRAYNET is particularly concerned with the socio-cultural aspect when discussing and implementing management and conservation strategies. The present Austrian meeting emphasized that with the topic "European native crayfish in relation to land-use and habitat deterioration: a special focus on Austropotamobius torrentium". The main objectives of the meeting was to define the status of Austropotamobius torrentium in the individual countries and to discuss necessary research activities and management strategies for crayfish protection and consequently to identify the necessary species protection programmes; to examine if legislation is working well in protecting vulnerable species; the state of advances in conservation genetics and how to make progress about the education of the public. A permanent connection between the 12 core members provides opportunities to check the needed lines of research and to prepare recommendations, a task to be completed for the final CRAYNET conference in 2005 (2-7 May, Firenze, Italy), entitled "European crayfish as heritage species linking research and management strategies to conservation and socioeconomic development". The Florence conference will summarize the most relevant themes discussed in the previous CRAYNET conferences, such as the status of European endangered crayfish species, the research activities conducted so far, and the management options adopted by the European countries. It also aims at developing common guidelines for the conservation of indigenous crayfish as heritage species. These purposes will be achieved through interdisciplinary discussion focusing on general issues related to freshwater biodiversity and its conservation. To this end, the conference will gather European and extra-European crayfish researchers together with ecologists, economists, geneticists, historians of science, managers, and zoologists. A relevant addendum of the CRAYNET conference will be the two-day International Workshop "Biological invasions in inland waters" (InWat), held under the auspices of the University of Florence. Through the analysis of empirical cases from diverse freshwater ecosystems, the Workshop will aim at finding the necessary basis for a quantification of the costs (ecological, economic, and social) of biological invasions and for an improvement of controls of aquatic nuisance species. These exchanges among scientists and managers are expected to lead to the proposal of actions to mitigate and/or to halt the invasive processes.

\section{ACKNOWLEDGEMENTS}

Thanks are due to the European Commission for funding CRAYNET activities (CRAYNET - EVK2-CT-2002-20013). I wish to thank once more Julian REYNOLDS for improving English language. 


\section{REFERENCES}

DEMERS A., REYNOLDS J., CIONI A., 2003. Habitat preference of different size classes of Austropotamobius pallipes in an Irish river. In: REYNOLDS J., SOUTY-GROSSET C. (eds): The endangered native crayfish Austropotamobius pallipes, Bioindicator and heritage species, CRAYNET, volume 1, Bull. Fr. Pêche Piscic., 370-371, 127-139.

EDGERTON B., JUSSILA J., 2004. Keynote presentation and roundtable session, Crayfish pathology in Europe: past, present and a programme for the future. In: TAUGBØL T., SOUTY-GROSSET C. (eds): European native crayfish with a special focus on Astacus astacus: linking socioeconomics and conservation, CRAYNET, volume 2, Bull. Fr. Pêche Piscic., 372-373, 473-482.

EDSMAN L., 2000. Crayfish conservation in Sweden, lesson to learn. In: Crayfish Conference Leeds, Rogers, D., Brickland, J. eds, 19-25. Environment agency, Leeds.

EDSMAN L., SMIETANA P., 2004. Exploitation, conservation and legislation. In: TAUGBØL T., SOUTY-GROSSET C. (eds): European native crayfish with a special focus on Astacus astacus: linking socioeconomics and conservation, CRAYNET, volume 2, Bull. Fr. Pêche Piscic., 372-373, 457-465.

FRATINI S., ZACCARA S., BARBARESI S., GRANDJEAN F., SOUTY-GROSSET C., CROSA G, GHERARDI F., 2005. Phylogeography of the threatened crayfish (genus Austropotamobius) in Italy: implications for its taxonomy and conservation. Heredity, 94, 108-118.

FÜREDER L., REYNOLDS J.D., 2003. Is Austropotamobius pallipes a good bioindicator? In: REYNOLDS J., SOUTY-GROSSET C. (eds): The endangered native crayfish Austropotamobius pallipes, Bioindicator and heritage species, CRAYNET, volume 1, Bull. Fr. Pêche Piscic., 370-371, 157-163.

FÜREDER L., OBERKOFLER B., HANEL R., LEITER J., THALER B., 2003. The freshwater crayfish Austropotamobius pallipes in South Tyrol: Heritage species and bioindicator. In: REYNOLDS J., SOUTY-GROSSET C. (eds), 2003: The endangered native crayfish Austropotamobius pallipes, Bioindicator and heritage species, CRAYNET, volume 1, Bull. Fr. Pêche Piscic., 370-371, 81-95.

GOUIN N., 2001. Apport des marqueurs nucléaires dans l'analyse de la structure génétique de l'écrevisse à pattes blanches Austropotamobius pallipes: implications pour sa conservation. Thèse de l'Université de Poitiers, $177 \mathrm{p}$.

GOUIN N., GRANDJEAN F., PAIN S., SOUTY-GROSSET C., REYNOLDS J. D., 2003. Origin and colonization history of the white-clawed crayfish, Austropotamobius pallipes, in Ireland. Heredity, 91, 70-77.

GRANDJEAN F., SOUTY-GROSSET C., 2000. Mitochondrial DNA variation and population genetic structure of the white-clawed crayfish Austropotamobius pallipes pallipes. Conservation Genetics, 1: 309-319.

GRANDJEAN F., FRELON-RAIMOND M., SOUTY-GROSSET C., 2000. A compilation of molecular data for the phylogeny of the genus Austropotamobius: One species or several? In: SOUTY-GROSSET C., GRANDJEAN F. (eds) Knowledge-based management of European native crayfish. Crayfish special, volume 4. Bull. Fr. Pêche Piscic., 367, 663-670.

GRANDJEAN F., HARRIS D.J., SOUTY-GROSSET C., CRANDALL K.A., 2000. Systematics of the European endangered crayfish species Austropotamobius pallipes (Decapoda: Astacidae). Journal Crustacean Biology, 20, 524-531. 
HOLDICH D.M., 2002. Distribution of crayfish in Europe and some adjoining countries. In: SOUTY-GROSSET C., GRANDJEAN F. (eds), Knowledge-based management of European native crayfish. Crayfish special, volume 4. Bull. Fr. Pêche Piscic., 367, 611-650.

HOLDICH D.M., 2003. Crayfish in Europe - an overview of their taxonomy, legislation, distribution, and crayfish plague outbreaks. In: SIBLEY P.J. (eds), Management and Conservation of Crayfish, 15-34. Environment Agency, Bristol.

HOLDICH D.M., ROGERS W.D., 2000. Habitat requirements of the white-clawed crayfish, Austropotamobius pallipes. In: ROGERS and BRICKLAND, J. Crayfish Conference Leeds, 109-121.

HOLDICH D.M., REYNOLDS J.D., EDSMAN L., 2002. Monitoring in conservation and management of indigenous crayfish populations. In: SOUTY-GROSSET C., GRANDJEAN F. (eds), Knowledge-based management of European native crayfish. Crayfish special, volume 4. Bull. Fr. Pêche Piscic., 367, 875-880.

PEAY S., 2000. Guidance on works affecting white-clawed crayfish. English Nature and the Environment Agency, $27 \mathrm{p}$.

PUKY M., REYNOLDS J.D., GRANDJEAN F., 2002. Education as a key to Decapod conservation. In: SOUTY-GROSSET C., GRANDJEAN F. (eds), Knowledge-based management of European native crayfish. Crayfish special, volume 4. Bull. Fr. Pêche Piscic., 367, 911-916.

REYNOLDS J.D., DEMERS A., MARNELL F., 2002. Managing an abundant crayfish resource for conservation. $A$. pallipes in Ireland. In: SOUTY-GROSSET C., GRANDJEAN F. (eds), Knowledge-based management of European native crayfish. Crayfish special, volume 4. Bull. Fr. Pêche Piscic., 367, 823-832.

SCHULZ R., SCHULZ H., 2004. Roundtable session 1, Threats to indigenous crayfish populations- Studies on a landscape level. In: TAUGBØL T., SOUTY-GROSSET C., 2004: European native crayfish with a special focus on Astacus astacus: linking socioeconomics and conservation, CRAYNET, volume 2., Bull. Fr. Pêche Piscic., 372-373, 449-457.

SIBLEY P.J., 2003. Conservation management and legislation - the UK experience. In: REYNOLDS J., SOUTY-GROSSET C. (eds): The endangered native crayfish Austropotamobius pallipes, Bioindicator and heritage species, CRAYNET, volume 1. Bull. Fr. Pêche Piscic., 370-371, 209-217.

SOUTY-GROSSET C., GRANDJEAN F., GOUIN N., 2003. Involvement of genetics in knowledge, stock management and conservation of Austropotamobius pallipes in Europe. In: REYNOLDS J., SOUTY-GROSSET C. (eds): The endangered native crayfish Austropotamobius pallipes, Bioindicator and heritage species, CRAYNET, volume 1. Bull. Fr. Pêche Piscic., 370-371, 167-180.

SOUTY-GROSSET C., GRANDJEAN F., GOUIN N., 2004. Conservation and management of native crayfish populations. Freshwater Crayfish, 14, 1-20.

SWAHN J.O., 2004. The cultural history of crayfish. In: TAUGBØL T., SOUTY-GROSSET C. (eds): European native crayfish with a special focus on Astacus astacus: linking socioeconomics and conservation, CRAYNET, volume 2. Bull. Fr. Pêche Piscic., 372-373, 243-262.

TAUGBØL T., PEAY S., 2004. Roundtable session 3, Reintroduction of native crayfish and habitat restoration. In: TAUGBØL T., SOUTY-GROSSET C. (eds): European native crayfish with a special focus on Astacus astacus: linking socioeconomics and conservation, CRAYNET, volume 2. Bull. Fr. Pêche Piscic., 372-373, 465-472. 
TROUILHÉ M.C., RICARD F., PARINET B., GRANDJEAN F., SOUTY-GROSSET C., 2003. Management of the white-clawed crayfish (Austropotamobius pallipes) in Western France: abiotic and biotic factors study, In: REYNOLDS J., SOUTY-GROSSET C. (eds): The endangered native crayfish Austropotamobius pallipes, Bioindicator and heritage species, CRAYNET, volume 1. Bull. Fr. Pêche Piscic., 370-371, 97-114.

VIGNEUX E., THIBAULT M., MARNELL F., SOUTY-GROSSET C., 2002. National legislation, EU directives and conservation. In: SOUTY-GROSSET C., GRANDJEAN F. (eds), Knowledge-based management of European native crayfish. Crayfish special, volume 4. Bull. Fr. Pêche Piscic., 367, 887-898. 
